Introduction to Michael B. Katz 2015 SSHA Memorial Session

Harvey J. Graff

History for Justice: Michael Katz and the History of Education

Leah N. Gordon

Michael Katz, Urban Optimist

Margaret O'Mara

Michael Katz's Contribution to Social and Social Welfare History

Mark J. Stern

Michael Katz and the Academic-Activist Tension

Merlin Chowkwanyun

\title{
Introduction to Michael B. Katz 2015 SSHA Memorial Session
}

Harvey J. Graff

I first met Michael Katz on a clear, cool autumn afternoon in 1970. I was an uncertain first-year graduate student at the University of Toronto intending to complete a doctorate in British history with a project on antisocialism. Feeling confused, anxious, and unsatisfied by my courses, I began to share my concerns with fellow students. One of them, who became a lifelong friend (and editor), suggested that I contact that "young professor up the street" in history of education at the Ontario Institute for Studies in Education who worked in the new social history. Having read Thernstrom, Tilly, E. P. Thompson, Eric Hobsbawm, Barrington Moore, and so forth, in a senior honors seminar, I drew up my courage and went to meet Michael.

That meeting changed my life and contributed not only to my success in graduate school but also to the course I followed as a historian and active member of university faculties and the world of scholars and scholarships. Michael—and his familyquickly became close personal friends. Michael was my advisor, in the broadest sense, for 44 years, and I had the poignant honor of dedicating my most recent book, Undisciplining Knowledge: Interdisciplinarity in the Twentieth Century (2015), to Michael as my "teacher, colleague, and friend." My colleagues beside me will join me in saying that.

In an obituary published in the Urban History Association Newsletter, SSHA past president Tom Sugrue wrote, "Michael B. Katz (1939-2014) was a model mentor and scholar, someone who fearlessly engaged the world outside the academy. He tackled America's most pressing social problems_-public education, inequality, poverty and welfare, urban policy_with deep passion and real rigor."

Michael B. Katz was Walter H. Annenberg Professor of History at the University of Pennsylvania. His work focused on three major areas: 
- The history of American education-The Irony of Early School Reform; Educational Innovation in Mid-Nineteenth Century Massachusetts (1968); Class, Bureaucracy, and Schools: The Illusion of Educational Change in America (1971); Reconstructing American Education (1987); and Public Education under Siege (2013).

- The history of urban social structure and family organization-The People of Hamilton, Canada West: Family and Class in a Mid-Nineteenth-Century City (1975); The Social Organization of Early Industrial Capitalism (1981); One Nation Divisible: What America Was and What It Is Becoming (2006); and Why Don't American Cities Burn? (2011).

- The history of social welfare and poverty-Poverty and Policy in American History (1983); In the Shadow of the Poorhouse: A Social History of Welfare in America (1986); The Undeserving Poor: From the War on Poverty to the War on Welfare (1989); The "Underclass" Debate: Views from History (1993); Improving Poor People: The Welfare State, the "Underclass," and Urban Schools as History (1995); The Price of Citizenship: Redefining the American Welfare State (2001); The Undeserving Poor: America's Enduring Confrontation with Poverty (2013); and The Mixed Economy of Social Welfare: Public/Private Relations in England, Germany, and the United States from the 1870s to the 1930s (1996).

At the time of his death, he was working on immigration and co-authored a report on immigration to Greater Philadelphia with the Brookings Institution and several prize-winning articles.

The contributors to this session are all fellow former students from Michael's three universities, reflecting his fields of interest and the length and breadth of his career. Not only do we span diverse fields of social, educational, urban, family, institutional, policy, welfare, reform, and related historical fields, together our degree dates range from 1975 to 2013. We also studied with him at the three universities at which he taught: Toronto, York, and Pennsylvania.

To set our stage, I quote a handful of passages from Michael's prize-winning The People of Hamilton (1975-40 years ago) in which I hear his voice especially clearly.

\section{Evoking Michael Katz}

From The People of Hamilton (1975):

(1) The predominance of ungrounded assumption over hard knowledge about past societies reflects partly the traditional concerns of historians, who have been more interested in politics, great men, governmental policy, and ideas than in the patterns made by the everyday lives of people. Although part of the problem has been interest, part has been the difficulty of the subject matter as well. (8) 
(2) [F]or a variety of reasons we are left either with incorrect notions or with ignorance about much of the past. That ignorance is especially harmful because it has led scholars on occasion to ask the wrong questions as they have formulated social theory or undertaken historical research. A "high proportion of sociological research," as Philip Abrams has written, "is in fact research on myths which sociologists have invented." (8-9)

(3) From these examples it should be clear that at this point the right questions remain more important than the right answers. One object of social history should be to formulate questions that will guide research in ways not only theoretically fruitful but historically appropriate. (9)

(4) It should be clear by now that this book is a mixture of hard data and rash speculation. The data can be interpreted in different ways, but at rock bottom they do provide a solid and enduring contribution which other historians who may disagree violently with what I offer as explanation nonetheless can use. One immense value of the sort of historical inquiry on which this book rests is that it offers historians the opportunity to build upon one another's work in a systematic and cumulative fashion. History never can become a science like physics or chemistry, but historians can increase enormously the extent to which the results of their research are useful in comparative inquiry, reproducible by other scholars and cumulative in character. (10)

(5) As for the speculations in this book, I hope they will be taken in the spirit in which they are offered. They are not propositions offered dogmatically, or absolute truths, or even, sometimes, very firmly grounded generalizations. They are interpretations which seem plausible, consistent with the data, and, I hope, useful to social theorists and historians. (10)

(6) The project on which this book rests was collaborative. For a few years many people worked in one capacity or another on the collection and analysis of the data. Their contributions influenced my thoughts profoundly. In particular, we tried to establish a working model of research in which a group of people exploited a common data base, each pursuing his own individual interests yet drawing on the group as a whole for support, criticism, and knowledge. (11)

(7) The collaborative nature of our work - the way in which we found it possible to reconcile the interests and desire for autonomy of individual scholars with the need for collective wisdom and energy in the analysis of the massive data base we were assembling — should be stressed. For historians traditionally are a lonely lot. The classic image of the historian is the scholar working alone with his books or manuscripts in a library, unable to carry on very much dialogue with anyone else. We, to the contrary, experienced the exhilaration of continually testing our ideas with a group which had an intimate knowledge of the same sources and techniques. Through periodic project meetings we sustained for a few years a collective and collegial intellectual life which enriched our own thinking and gave us a new perspective on the organization of scholarly activity. . . . The project meetings were the best seminars that most of us had attended in a long time. (12) 


\title{
References
}

Graff, Harvey J. (2015) Undisciplining Knowledge: Interdisciplinarity in the Twentieth Century. Baltimore: Johns Hopkins University Press.

Katz, Michael B. (1968) The Irony of Early School Reform; Educational Innovation in Mid-Nineteenth Century Massachusetts. Cambridge, MA: Harvard University Press (new ed., New York: Teachers College Press, 2001).

(1971) Class, Bureaucracy, and Schools: The Illusion of Educational Change in America. New York: Praeger (exp. ed., 1975).

(1975) The People of Hamilton, Canada West: Family and Class in a Mid-Nineteenth-Century City. Cambridge, MA: Harvard University Press.

(1983) Poverty and Policy in American History. New York: Academic Press.

(1986) In the Shadow of the Poorhouse: A Social History of Welfare in America. New York: Basic

Books (10th anniversary ed., 1996).

_ (1987) Reconstructing American Education. Cambridge, MA: Harvard University Press.

(1989) The Undeserving Poor: From the War on Poverty to the War on Welfare. New York:

Pantheon.

(1995) Improving Poor People: The Welfare State, the "Underclass," and Urban Schools as History.

Princeton, NJ: Princeton University Press.

(2001) The Price of Citizenship: Redefining the American Welfare State. New York: Metropolitan Books (updated ed., University of Pennsylvania Press, 2008).

(2011) Why Don't American Cities Burn? Philadelphia: University of Pennsylvania Press.

(2013) The Undeserving Poor: America's Enduring Confrontation with Poverty, 2nd ed. New York: Oxford University Press.

Katz, Michael B., ed. (1993) The "Underclass" Debate: Views from History. Princeton, NJ: Princeton University Press.

Katz, Michael B., and Mark J. Stern (2006) One Nation Divisible: What America Was and What It Is Becoming. New York: Russell Sage Foundation.

Katz, Michael B., and Mike Rose, eds. (2013) Public Education Under Siege. Philadelphia: University of Pennsylvania Press.

Katz, Michael B., and Christoph Sachsse, eds. (1996) The Mixed Economy of Social Welfare: Public/Private Relations in England, Germany, and the United States from the 1870s to the 1930s. BadenBaden: Nomos Verglagsgesellschaft.

Katz, Michael B., Michael J. Doucet, and Mark J. Stern (1981) The Social Organization of Early Industrial Capitalism. Cambridge, MA: Harvard University Press.

doi:10.1017/ssh.2017.30

\section{History for Justice: Michael Katz and the History of Education}

\author{
Leah N. Gordon
}

I recently told one of my graduate students that I was contributing to the panel on which these papers are based, and he replied that reading Michael Katz's The Irony of Early School Reform: Educational Innovation in Mid-Nineteenth Century Massachusetts (2001a) led him to apply to graduate school. My story is the same. When I was deciding whether to pursue a graduate degree, Katz's Class, Bureaucracy, and Schools (1975) convinced me to study the history of education. What Katz's scholarship, and later his mentorship, taught me was that one could be a historian with an eye toward justice, that one need not compartmentalize scholarly, political, and ethical commitments. 